\title{
Chemical Composition, Antioxidant and Antimicrobial Activities of the Essential Oil of Scutia buxifolia Reissek Leaves
}

\author{
Aline Augusti Boligon ${ }^{1 *}$, Thiago Guilherme Schwanz ${ }^{2}$, Thiele Faccim de Brum¹, Janaína Kieling Frohlich ${ }^{1}$, Letícia Nunes ${ }^{1}$, Débora Nunes \\ Mario $^{3}$, Sydney Hartz Alves ${ }^{3}$ and Margareth Linde Athayde ${ }^{1}$
}

${ }^{1}$ Phytochemical Research Laboratory, Department of Industrial Pharmacy, Federal University of Santa Maria, Build 26, room 1115, Santa Maria, RS 97105-900, Brazil ${ }^{2}$ Center for Analysis and Organic Research (NAPO), Department of Chemistry, Federal University of Santa Maria, Build 15, Santa Maria, RS 97105-900, Brazil ${ }^{3}$ Mycological Research Laboratory, Department of Microbiology and Parasitology, Federal University of Santa Maria, Build 20, Santa Maria, RS 97105-900, Brazil

\begin{abstract}
The chemical composition, antioxidant and antibacterial activities of essential oil isolated by hydrodistillation from the leaves parts of Scutia buxifolia were evaluated. The chemical composition was analyzed by gas chromatography (GC-FID) and gas chromatography-mass spectrometry (GC-MS). Twenty-five substances were identified, consisting of a complex mixture of sesquiterpenes $(73.69 \%)$ and monoterpenes $(18.74 \%)$. The main components in the oil were spathulenol $(27.09 \%), \beta$-cubebene $(11.26 \%)$, germacrene D $(9.81 \%)$, carvacrol $(7.01 \%)$, globulol (5.36\%), $\alpha$-copaene (4.17\%), $\gamma$-eudesmol (3.59\%), thymol (3.27\%), 1,8-cineol (3.08\%), $p$-cymene $(2.56 \%)$, a-eudesmol $(2.34 \%)$, $\beta$-elemene $(2.04 \%)$, butylated hydroxytoluene $(2.00 \%)$ along with eugenol acetate, $n$-hexanol, $\alpha$-pinene, $\alpha$-humulene, eugenol, humulene epoxide, phytol as minor constituents. The antioxidant property of the oil was assessed by free radical scavenging (DPPH) assay. S. buxifolia essential oil presented interesting radical scavenging activity $\left(\mathrm{IC}_{50}=13.62 \pm 0.17 \mu \mathrm{g} / \mathrm{mL}\right)$. The antibacterial properties of the oils also was tested by broth microdilution method and was effective only against $S$. aureus and $E$. coli (MIC=500 and $750 \mu \mathrm{g} / \mathrm{mL}$, respectively). To the best of our knowledge, this is the first study of the composition, antioxidant and antimicrobial activities of essential oil from the S. buxifolia collected from Brazil.
\end{abstract}

Keywords: Scutia buxifolia; Essential oil; Antioxidant; Antimicrobial

\section{Introduction}

Essential oils in plant are complex volatile mixtures exist at low concentrations and are commonly found in aromatic plants [1,2]. Studies have demonstrated beneficial properties of essential oils in the prevention and treatment of cancer, cardiovascular diseases including atherosclerosis and thrombosis, as well as their bioactivity as antibacterial, antiviral, antioxidants, antidiabetic, anti-inflammatory agents, local anaesthetic and immunomodulatory [1,3-5].

Biologically, the essential oils perform the function of adaptation of the plant to the environment, acting in the defense against the attack of predators, attraction of pollination agents, protection against water loss and temperature increase and as inhibitors of germination $[6,7]$. Economically, they are employed in food, cosmetic and cleaning products industries, as well as in alternative medicine due to their many therapeutic properties.

Scutia buxifolia Reissek belong to the Rhamnaceae family and is popularly known as "coronilha". It is native tree from South America, with a dispersion area that comprises Rio Grande do Sul State in Brazil, and the countries Argentina and Uruguay. The root bark infusion is popularly used as cardiotonic, antihypertensive and diuretic [8]. Antimicrobial activities of some cyclopeptide alkaloids isolated from the root bark of this species were reported by Morel et al. [9] using the bioautography method. Cytotoxicity of extracts from leaves, twigs and stem bark of the plant was evaluated by the Artemia salina assay, as well as the antimicrobial activity against a panel of microorganism strains [10]. Extracts from the leaves and stem bark of S. buxifolia were effective inhibitors of TBARS production and also presented DPPH scavenger activity [11].

The literature search did not reveal any report on the essential oil composition of $S$. buxifolia. The aim of the present work was to determine the chemical composition and evaluate the antioxidant and antimicrobial activity of the essential oil from leaves of S. buxifolia, accessed by gas chromatography (GC-FID) and gas chromatographymass spectrometry (GC-MS) analysis, 1,1-diphenil-2-picrylhydrazil (DPPH) method and microdilution assay.

\section{Materials and Methods}

\section{Plant material}

Scutia buxifolia (Rhamnaceae) leaves were collected in Dom Pedrito, State of Rio Grande do Sul, Brazil, on June of 2011 (coordinates $30^{\circ} 59^{\prime} 09^{\prime \prime} \mathrm{S}$ and $54^{\circ} 27^{\prime} 44^{\prime \prime} \mathrm{W}$ ). It was identified and archived as voucher specimens in the herbarium of Department of Biology at Federal University of Santa Maria by register number SMBD 10919.

\section{Extraction of the essential oil}

The fresh material (250 g) of the plant leaves was extracted using a hydrodistillation process in a Clevenger apparatus for 4 hours. Oil was dried over anhydrous sodium sulphate and, after filtration, stored at $-4^{\circ} \mathrm{C}$ until test and analysis. The yield in terms of percentage of the fresh weight of the leaves was determined.

*Corresponding author: Aline Augusti Boligon, Phytochemical Research Laboratory, Department of Industrial Pharmacy, Federal University of Santa Maria, Build 26, Room 1115, Santa Maria, RS 97105-900, Brazil, Tel: +55 553220 9618; Fax: +55 55 32208248; E-mail: alineboligon@hotmail.com

Received November 22, 2012; Accepted December 09, 2012; Published December 13, 2012

Citation: Boligon AA, Schwanz TG, de Brum TF, Frohlich JK, Nunes L, et al (2012) Chemical Composition, Antioxidant and Antimicrobial Activities of the Essential Oil of Scutia buxifolia Reissek Leaves. Pharmaceut Anal Acta 3: 199. doi:10.4172/2153-2435.1000199

Copyright: (c) 2012 Boligon AA, et al. This is an open-access article distributed under the terms of the Creative Commons Attribution License, which permits unrestricted use, distribution, and reproduction in any medium, provided the original author and source are credited. 
Citation: Boligon AA, Schwanz TG, de Brum TF, Frohlich JK, Nunes L, et al. (2012) Chemical Composition, Antioxidant and Antimicrobial Activities of the Essential Oil of Scutia buxifolia Reissek Leaves. Pharmaceut Anal Acta 3: 199. doi:10.4172/2153-2435.1000199

Page 2 of 4

\section{Gas chromatography (GC-FID)}

The gas chromatography (GC) analyses were carried out using an Agilent. Technologies 6890N GC-FID system, equipped with DB-5 capillary column $(30 \mathrm{~m} \times 0.25 \mathrm{~mm}$; film thickness $0.25 \mathrm{~mm})$ and connected to an FID detector. The injector and detector temperatures were set to $280^{\circ} \mathrm{C}$. The carrier gas was helium, at a flow rate of $1.3 \mathrm{~mL} /$ min. The thermal programmer was $50-300^{\circ} \mathrm{C}$ at a rate of $5^{\circ} \mathrm{C} / \mathrm{min}$. Two replicates of samples were processed in the same way. Component relative concentrations were calculated based on GC peak areas without using correction factors. The injection volume of the oil was $1 \mu \mathrm{L}[4,12]$.

\section{Gas chromatography-mass spectrometry (GC-MS)}

GC-MS analyses were performed on a Agilent Technologies AutoSystem XL GC-MS system operating in the EI mode at $70 \mathrm{eV}$, equipped with a split/splitless injector $\left(250^{\circ} \mathrm{C}\right)$. The transfer line temperature was $280^{\circ} \mathrm{C}$. Helium was used as carrier gas $(1.3 \mathrm{~mL} / \mathrm{min})$ and the capillary columns used were an HP $5 \mathrm{MS}$ ( $30 \mathrm{~m} \times 0.25 \mathrm{~mm}$; film thickness $0.25 \mathrm{~mm})$ and an HP Innowax $(30 \mathrm{~m} \times 0.32 \mathrm{~mm}$ i.d., film thickness $0.50 \mathrm{~mm}$ ). The temperature programmer was the same as that used for the GC analyses. The injected volume was $1 \mu \mathrm{L}$ of the essential oil.

\section{Identification of the components}

Identification of the constituents was performed on the basis of retention index (RI), determined with reference of the homologous series of n-alkanes, $\mathrm{C}_{7}-\mathrm{C}_{30}$, under identical experimental conditions, comparing with the mass spectra library search (NIST and Wiley), and with the mass spectra literature date Adams [13]. The relative amounts of individual components were calculated based on the CG peak area (FID response).

\section{Qualitative analysis of antioxidant activity}

Ten microlitres of 1:50 dilution of the essential oil in methanol was applied to TLC plates (silica gel $60 \mathrm{GF}_{254}$ ), quercetin and ascorbic acid (Sigma-Aldrich, $\geq 98 \%$ HPLC) standards also were used. The TLC plate was sprayed with a $0.2 \%$ 1,1-diphenyl-2-picrylhydrazyl (DPPH) solution in methanol and left at room temperature for 30 minutes. Active compounds appear as yellow spots against a purple background, indicating possible antioxidant activity [14].

\section{Quantitative analysis of antioxidant activity}

The antioxidant activity of the essential oil was evaluated by monitoring their ability in quenching the stable free radical DPPH, according to a slightly modified method previously described by Mensor et al. [14]. Spectrophotometric analysis was used to measure the free radical-scavenging capacity and to determine the scavenging concentration or inhibitory concentration $\left(\mathrm{IC}_{50}\right)$. The $\mathrm{DPPH}$ quenching ability was expressed as IC $_{50}$ (the essential oil concentration $(\mu \mathrm{g} / \mathrm{mL})$ required to inhibit $50 \%$ of the DPPH in the assay medium).

Six different ethanol dilutions of essential oil at 250, 125, 62.5, $31.25,15.62$ and $7.81 \mu \mathrm{g} / \mathrm{mL}$ were mixed with $1.0 \mathrm{~mL}$ of DPPH 0.3 $\mathrm{mM}$ in ethanol solution. After $30 \mathrm{~min}$, absorption was measured at $518 \mathrm{~nm}$, where the radical DPPH shows maximum absorption. A solution of DPPH $(1 \mathrm{~mL} ; 0.3 \mathrm{mM})$ in ethanol $(2.5 \mathrm{~mL})$ was used as a negative control and ascorbic acid in the same concentrations used for the essential oil provided the positive control. Ethanol was used to calibrate the spectrophotometer. The test was performed in triplicate and the calculation of the antioxidant activity followed the equation:
\% Inhibition $=\left[\left(A_{0}-A_{1}\right) / A_{0}\right] \times 100$, where $A_{0}$ was the absorbance of the control sample (without essential oil) and $A_{1}$ was the absorbance in the presence of the sample [11].

\section{Antimicrobial assay determination}

The essential oil was evaluated against Candida albicans ATCC 28967, Cryptococcus neoformans ATCC 2857, K. pneumoniernaae ATCC 700603, P. aeruginosa ATCC 27853, E. faecalis ATCC 51299, P. mirabilis ATCC 7002, S. aureus ATCC 29213, Malassezia sp., Aspergillus sp., Aeromonas sp., S. aureus and E. coli (clinical isolates). The minimal inhibitory concentration (MIC) of the oil against the test microorganisms were determined by the broth microdilution method M27-A2 [15]. The experiments were repeated twice and the results were determined as an average value. Six different dilutions (1000, $750,500,250,125$, and $62.5 \mu \mathrm{g} / \mathrm{mL}$ ) were prepared in DMSO. Bacterial strains were cultured overnight at $37^{\circ} \mathrm{C}$ in Mueller-Hinton agar. Yeasts were cultured overnight at $30^{\circ} \mathrm{C}$ in Potato dextrose agar. The first column of the plate was reserved for negative control wells (without inoculants) and the last column, for the positive growth control wells (without antimicrobial agents). The MIC was considered as the lowest concentration of the essential oil inhibiting the total growth of microorganisms. MIC was detected by lack of visual turbidity (matching the negative growth control).

\section{Statistical analysis}

The obtained antioxidant and antimicrobial results were stated in mean \pm standard deviation of three replicates.

\section{Results and Discussion}

The pale yellowish essential oil of the fresh leaves of $S$. buxifolia was obtained by hydrodistillation in the yield of $0.4 \%$. Essential oil was analyzed by GC-FID and GC-MS systems and the oil components were identified both quantitatively and qualitatively. Twenty-five components, representing $98.38 \%$ of the total composition, were identified, of which $73.69 \%$ are sesquiterpenes and $18.74 \%$ are monoterpenes (Table 1).

The main components in the oil were spathulenol (27.09\%), $\beta$-cubebene (11.26\%), germacrene D (9.81\%), carvacrol $(7.01 \%)$, globulol (5.36\%), $\alpha$-copaene (4.17\%), $\gamma$-eudesmol (3.59\%), thymol (3.27\%), 1,8-cineol (3.08\%), p-cymene (2.56\%), $\alpha$-eudesmol (2.34\%), $\beta$-elemene $(2.04 \%)$, butylated hydroxytoluene $(2.00 \%)$ along with eugenol acetate, $n$-hexanol, $\alpha$-pinene, $\alpha$-humulene, eugenol, humulene epoxide, phytol as minor constituents. In addition, $p$-cymene showed a maximum when carvacrol was at its minimum, which is in agreement with the literature, reporting that $p$-cymene is the precursor of carvacrol [16].

Spathulenol, the most abundant component of this oil, has also been reported in the oil of other species such as Baccharis uncinella (16.41\%), Stevia rebaudiana (15.41\%), Origanum vulgare (11.67\%) and Baccharis dracunculifolia (9.54\%) [17-19]. The second major component of the oil, $\beta$-cubebene, has also been found in the oils of Dendropanax morbifera [20] and Cinnamomum osmophloeum [21] in about $4.19 \%$ and $59.4 \%$, respectively. Germacrene $\mathrm{D}$, the third major compound present, has also been found in the oil of Artemisia annua (15.64\%), Baccharis uncinella (14.87\%), Campomanesia adamantium (11.82\%), Tagetes minuta (10.00\%) and Origanum vulgare $(8.11 \%)$ $[19,22]$.

Many in vitro studies have addressed the antioxidant and radicalscavenging properties of essential oils $[1,23]$. In particular, DPPH 
Citation: Boligon AA, Schwanz TG, de Brum TF, Frohlich JK, Nunes L, et al. (2012) Chemical Composition, Antioxidant and Antimicrobial Activities of the Essential Oil of Scutia buxifolia Reissek Leaves. Pharmaceut Anal Acta 3: 199. doi:10.4172/2153-2435.1000199

Page 3 of 4

\begin{tabular}{|c|c|c|c|c|c|}
\hline Rt (min) & Compounds & (\%) & $\mathbf{R l}^{\mathbf{a}}$ & $\mathbf{R I}^{\mathbf{b}}$ & Mol. Formula \\
\hline & \multicolumn{5}{|l|}{ Monoterpenes } \\
\hline 3.261 & a-Pinene & 1.27 & 939 & 939 & $\mathrm{C}_{10} \mathrm{H}_{16}$ \\
\hline 3.880 & $\beta$-Pinene & 0.42 & 981 & 980 & $\mathrm{C}_{10} \mathrm{H}_{16}$ \\
\hline 10.625 & $p$-Cymene & 2.56 & 1026 & 1026 & $\mathrm{C}_{10} \mathrm{H}_{14}$ \\
\hline 11.381 & 1,8-Cineol & 3.08 & 1029 & 1033 & $\mathrm{C}_{10} \mathrm{H}_{18} \mathrm{O}$ \\
\hline 16.153 & Thymol & 3.27 & 1288 & 1290 & $\mathrm{C}_{10} \mathrm{H}_{14} \mathrm{O}$ \\
\hline 16.947 & Carvacrol & 7.01 & 1298 & 1298 & $\mathrm{C}_{10} \mathrm{H}_{14} \mathrm{O}$ \\
\hline \multirow[t]{2}{*}{18.042} & Eugenol & 1.13 & 1357 & 1356 & $\mathrm{C}_{10} \mathrm{H}_{12} \mathrm{O}_{2}$ \\
\hline & \multicolumn{5}{|l|}{ Sesquiterpenes } \\
\hline 19.511 & Thymol acetate & 0.92 & 1357 & 1355 & $\mathrm{C}_{12} \mathrm{H}_{16} \mathrm{O}_{2}$ \\
\hline 23.760 & a-Copaene & 4.17 & 1378 & 1376 & $\mathrm{C}_{15} \mathrm{H}_{24}$ \\
\hline 25.934 & $\beta$-Cubebene & 11.26 & 1400 & 1390 & $\mathrm{C}_{15} \mathrm{H}_{24}$ \\
\hline 28.486 & $\beta$-Elemene & 2.04 & 1390 & 1391 & $\mathrm{C}_{15} \mathrm{H}_{24}$ \\
\hline 28.627 & Methyl eugenol & 0.49 & 1400 & 1401 & $\mathrm{C}_{11} \mathrm{H}_{14} \mathrm{O}_{2}$ \\
\hline 29.002 & a-Humulene & 1.21 & 1454 & 1454 & $\mathrm{C}_{15} \mathrm{H}_{24}$ \\
\hline 30.165 & Germacrene D & 9.81 & 1477 & 1480 & $\mathrm{C}_{15} \mathrm{H}_{24}$ \\
\hline 31.931 & Butylated hydroxytoluene & 2.00 & 1509 & 1512 & $\mathrm{C}_{15} \mathrm{H}_{24} \mathrm{O}$ \\
\hline 32.471 & Eugenol acetate & 1.55 & 1537 & 1536 & $\mathrm{C}_{12} \mathrm{H}_{16} \mathrm{O}_{3}$ \\
\hline 33.502 & Spathulenol & 27.09 & 1577 & 1576 & $\mathrm{C}_{15} \mathrm{H}_{24} \mathrm{O}$ \\
\hline 35.099 & Globulol & 5.36 & 1583 & 1583 & $\mathrm{C}_{15} \mathrm{H}_{26} \mathrm{O}$ \\
\hline 35.710 & Humulene epoxide & 1.08 & 1598 & 1606 & $\mathrm{C}_{15} \mathrm{H}_{24} \mathrm{O}$ \\
\hline 36.420 & Y-Eudesmol & 3.59 & 1630 & 1630 & $\mathrm{C}_{15} \mathrm{H}_{26} \mathrm{O}$ \\
\hline 40.015 & Cubenol & 0.78 & 1643 & 1642 & $\mathrm{C}_{15} \mathrm{H}_{26} \mathrm{O}$ \\
\hline \multirow[t]{2}{*}{43.127} & $\alpha$-Eudesmol & 2.34 & 1651 & 1652 & $\mathrm{C}_{15} \mathrm{H}_{26} \mathrm{O}$ \\
\hline & \multicolumn{5}{|l|}{ Other } \\
\hline 5.618 & n-Hexanol & 4.43 & 867 & 867 & $\mathrm{C}_{6} \mathrm{H}_{14} \mathrm{O}$ \\
\hline 34.701 & Hexadecanol & 0.32 & 1871 & 1879 & $\mathrm{C}_{16} \mathrm{H}_{34} \mathrm{O}$ \\
\hline 47.095 & Phytol & 1.00 & 1957 & 1949 & $\mathrm{C}_{20} \mathrm{H}_{40} \mathrm{O}$ \\
\hline 54.32 & a-tocoferol & 0.24 & 2960 & - & $\mathrm{C}_{29} \mathrm{H}_{50} \mathrm{O}_{2}$ \\
\hline \multicolumn{2}{|c|}{ Total identified (\%) } & 98.38 & & & \\
\hline
\end{tabular}

$[16,18,23]$, these results proved that the essential oil from S. buxifolia leaf possess significant antioxidant properties.

For this oil, the medicinal benefit derived from their use may include prevention of oxidative damage and subsequent disease progression. Essential oils are complex mixtures and the determination of the component(s) responsible of the activity is difficult. Antioxidant activity of essential oils has often been attributed to the presence of phenolic constituents, especially spathulenol, carvacrol and thymol $[16,18,25,26]$. This association was confirmed in our study, but other compounds also seem to play an important role such as eugenol $\left(\mathrm{IC}_{50}=1.26 \mu \mathrm{g} / \mathrm{mL}\right.$ by DPPH method), $\beta$-cubebene $\left(\mathrm{IC}_{50}=19.3 \mu \mathrm{g} / \mathrm{mL}\right)$, butylated hydroxytoluene (BHT) and $p$-cymene [21,27-29]; these compounds are also present in the essential oil of S. buxifolia, and may account, in part, the good antioxidant potential reported here. The results presented here may contribute to the knowledge of the antioxidant potential of the essential oil and provide some information for its uses.

The essential oil of $S$. buxifolia leaves was tested also against 11 microorganisms; the antimicrobial screening is summarized in table 2. The essential oil showed only moderately activity against $S$. aureus and E. coli (MIC $=500$ and $750 \mu \mathrm{g} / \mathrm{mL}$, repectively), previous study describes the activity of $S$. buxifolia leaves against $S$. aureus [11]. Sesquiterpenoids spathulenol, $\beta$-cubebene, germacrene $\mathrm{D}$ and carvacrol were the main components identified in this essential oil and may be responsible, in part, for the antimicrobial activity described, since that spathulenol [30] and carvacrol [16,31] have been reported to present notable antimicrobial activity against bacterial infections. Spathulenol showed also a decrease in the proliferation of lymphocytes demonstrating immunomodulatory effects [5].

The antimicrobial activity of thymol $(3.27 \%$ in the essential oil of S. buxifolia) has been confirmed on bacteria such as E. coli [32]. Thymol has been shown to cause disruption of the cellular membrane, inhibition of ATPase activity, and release of intracellular ATP and other constituents [26,33]. The spathulenol, major compound described in the essential oil of S. buxifolia leaves (27.09\%), evidenced a high activity against the fungi strains dermatophytes as T. mentagrophytes and M. gypseum with MIC and MFC values ranging from 32 to $64 \mu \mathrm{g} /$ $\mathrm{ml}$. Furthermore, the MIC value against C. lactis-condensi and the MIC and MFC values against $P$. purpurogenum for the spathulenol were $32 \mu \mathrm{g} / \mathrm{ml}$ [17]. However, in our work that was not observed, since the essential oil of the $S$. buxifolia showed no activity against strains of fungi.

In conclusion, the analysis of the chemical composition of the essential oil of this plant and the preliminary evaluation of its be observed immediately after spraying DPPH reagent on the TLC plate, suggesting some antioxidant activity for this oil, with intensity and color similar to quercetin and ascorbic acid used as standards. However, in order to get relevant data, a single method for testing antioxidant activities of essential oils is not recommended due to their complex composition. So, this test was the first step in the screening of the potential activity of this essential oil and DPPH test quantitative also was performed.

In the DPPH assay quantitative, antioxidants are typically characterized by their $\mathrm{IC}_{50}$ value, concentration necessary to reduce $50 \%$ of DPPH radical. The efficiency of the essential oil of S. buxifolia and ascorbic acid standard were evaluated for this method, and presented $\mathrm{IC}_{50}$ values of $13.62 \pm 0.17$ and $15.98 \pm 1.30 \mu \mathrm{g} / \mathrm{mL}$, respectively; compared to Thymbra capitatus $\left(\mathrm{IC}_{50}=19.27 \mu \mathrm{g} / \mathrm{mL}\right.$ ), Pistacia atlantica $\left(\mathrm{IC}_{50}=18.95 \mu \mathrm{g} / \mathrm{mL}\right)$, Stevia rebaudiana $\left(\mathrm{IC}_{50}=19.26 \mu \mathrm{g} / \mathrm{mL}\right)$, Acacia Senegal $\left(\mathrm{IC}_{50}=17.89 \mu \mathrm{g} / \mathrm{mL}\right), M$. peregrinum $\left(\mathrm{IC}_{50}=13.48 \mu \mathrm{g} / \mathrm{mL}\right)$

\begin{tabular}{|l|l|}
\hline Microorganisms & Essential oil $(\boldsymbol{\mu g} / \mathbf{m L})$ \\
\hline C. albicans & $>1000.00$ \\
\hline C. neoformans & $>1000.00$ \\
\hline K. pneumoniernaae & $>1000.00$ \\
\hline P. aeruginosa & $>1000.00$ \\
\hline E. faecalis & $>1000.00$ \\
\hline P. mirabilis & $>1000.00$ \\
\hline Malassezia sp. & $>1000.00$ \\
\hline Aspergillus sp. & $>1000.00$ \\
\hline Aeromonas sp. & $>1000.00$ \\
\hline S. aureus & 500.00 \\
\hline E. coli & 750.00 \\
\hline
\end{tabular}

Table 2: Minimal inhibitory concentrations (MIC) of essential oil of the S. buxifolia leaves. 
Citation: Boligon AA, Schwanz TG, de Brum TF, Frohlich JK, Nunes L, et al. (2012) Chemical Composition, Antioxidant and Antimicrobial Activities of the Essential Oil of Scutia buxifolia Reissek Leaves. Pharmaceut Anal Acta 3: 199. doi:10.4172/2153-2435.1000199

antioxidant and antimicrobial activity is the first work described in the literature for this species, and, taken together, the data obtained here inspire more studies supporting the possibility of linking the chemical contents with particular biological properties.

\section{Acknowledgments}

The authors would like to thank the professors from NAPO (Center for Analysis and Organic Research at Federal Universtity of Santa Maria) for providing the CG/MS chromatograms and spectra and A.F. Morel (Department of Chemistry at Federal University of Santa Maria) for the assessment of the $n$-alkane series. The authors thank the financial support of CAPES and CNPq (Coordenação de Aperfeiçoamento de Pessoal de Nível Superior and Conselho Nacional de Desenvolvimento Científico e Tecnológico)/Brazil.

\section{References}

1. Edris AE (2007) Pharmaceutical and therapeutic potentials of essential oils and their individual volatile constituents: a review. Phytother Res 21: 308-323.

2. Kahriman N, Yaylı K, Yücel M, Karaoglu SA, Yaylı N (2012) Chemical constituents and antimicrobial activity of the essential oil from Vicia dadianorum extracted by hydro and microwave distillations. Rec Nat Prod 6: 49-56.

3. Passos GF, Fernandes ES, da Cunha FM, Ferreira J, Pianowski LF, et al (2007). Anti-inflammatory and anti-allergic properties of the essential oil and active compounds from Cordia verbenacea. J Ethnopharmacol 110: 323-333.

4. Nazemiyeh H, Lotfipoor F, Delazar A, Razavi SM, Asnaashari S, et al. (2011) Chemical composition, and antibacterial and free-radical- scavenging activities of the essential oils of a citronellol producing new chemotype of Thymus pubescens Boiss. \& Kotschy ex Celak. Rec Nat Prod 5: 184-192.

5. Ziaei A, Ramezani M, Wright L, Paetz C, Schneider B, et al. (2011) Identification of spathulenol in Salvia mirzayanii and the immunomodulatory effects. Phytother Res 25: 557-562.

6. Feresin GE, Tapia A, Lopèz SN, Zacchino SA (2001) Antimicrobial activity of plants used in traditional medicine of San Juan province, Argentine. J Ethnopharmacol 78: 103-107

7. Jassim SA, Naji MA (2003) Novel antiviral agents: a medicinal plant preservative. J Appl Microbiol 95: 412-427.

8. Wasicky R, Wasicky M, Joachimovits R (1964) Initial evaluation and Coronilha Scutia buxifolia Reissek. Planta Méd 12: 13-25.

9. Morel AF, Maldaner G, Ilha V, Missau F, Silva UF, et al. (2005) Cyclopeptide alkaloids from Scutia buxifolia Reiss and their antimicrobial activity. Phytochemistry 66: 2571-2576.

10. Boligon AA, Janovik V, Frohlich JK, Spader TB, Froeder ALF, et al. (2012) Antimicrobial and cytotoxic activities of leaves, twigs and stem bark of Scutia buxifolia Reissek. Nat Prod Res 26: 939-944.

11. Boligon AA, Pereira RP, Feltrin AC, Machado MM, Janovik V, et al. (2009) Antioxidant activities of flavonol derivatives from the leaves and stem bark of Scutia buxifolia Reiss. Bioresour Technol 100: 6592-6598.

12. Verma RS, Padalia RC, Chanotiya CS, Chauhan A (2010) Chemica investigation of the essential oil of Thymus linearis (Benth. ex Benth) from western Himalaya, India. Nat Prod Res 24: 1890-1896.

13. Adams RP (1995) Identification of essential oil components by Gas Chromatography/Mass spectroscopy. Allured Publishing Corporation: Illinois USA, 456.

14. Mensor LL, Menezes FS, Leitão GG, Reis AS, dos Santos TC, et al. (2001) Screnning of Brazilian plant extracts for antioxidant activity by the use of DPPH free radical method. Phytother Res 15: 127-130.

15. National Committee for Clinical Laboratory Standards (2002) Reference method for broth dilution antifungal susceptibility testing of yeasts.

16. Bounatirou S, Smiti S, Miguel MG, Faleiro L, Rejeb MN, et al. (2007) Chemical composition, antioxidant and antibacterial activities of the essential oils isolated from Tunisian Thymus capitatus Hoff. et Link. Food Chem 105: 146-155.

17. Al-Ja'fari AH, Vila R, Freixa B, Tomi F, Casanova J, et al. (2011) Composition and antifungal activity of the essential oil from the rhizome and roots of Ferula hermonis. Phytochemistry 72: 1406-1413.
18. Muanda FN, Soulimani R, Diop B, Dicko A (2011) Study on chemical composition and biological activities of essential oil and extracts from Stevia rebaudiana Bertoni leaves. LWT - Food Science Technology 44: 1865-1872.

19. Xavier VB, Vargas RMF, Cassel E, Lucas AM, Santos MA, et al. (2011) Mathematical modeling for extraction of essential oil from Baccharis spp. by steam distillation. Ind Crops Prod 33: 599-604.

20. Chung III-M, Seo SH, Kang EY, Park SD, Park WH, et al. (2010) Chemical composition and larvicidal effects of essential oil of Dendropanax morbifera against Aedes aegypti L. Biochem Syst Ecol 37: 470-473.

21. Lin KH, Yeh SY, Lin MY, Shih MC, Yang KT, et al. (2007) Major chemotypes and antioxidative activity of the leaf essential oils of Cinnamomum osmophloeum Kaneh. from a clonal orchard. Food Chem 105: 133-139.

22. Ghiasvand AR, Nasseri M, Farsizaeh S, Meshkatalsadat MH, Sadeghi-Sarab $\mathrm{R}$, et al. (2011) Chemical Characterization of Cultivated Tagetes minuta L. by use of ultrasound-assisted head space SPME and GC-MS. Chromatographia 73: 1031-1035

23. Gourine N, Yousfi M, Bombarda I, Nadjemi B, Stocker $P$ et al (2010) Antioxidant activities and chemical composition of essential oil of Pistacia atlantica from Algeria. Ind Crops Prod 31: 203-208.

24. Brand-Williams W, Cuvelier ME, Berset C (1995) Use of free radical method to evaluate antioxidant activity. LWT Food Science and Technology 28: 25-30.

25. Hazzit M, Baaliouamer A, Veríssimo AR, Faleiro ML, Miguel MG (2009) Chemical composition and biological activities of Algerian Thymus oils. Food Chem 116: 714-721.

26. Viuda-Martos M, Mohamady MA, Fernández-López J, Abd EIRazik KA, Omer EA, et al. (2011) In vitro antioxidant and antibacterial activities of essentials oils obtained from Egyptian aromatic plants. Food Control 22: 1715-1722.

27. Gulcin I, Sat IG, Beydemir S, ElmastaS M, Kufrevioglu OI (2004) Comparison of antioxidant activity of clove (Eugenia Caryophylata Thumb.) buds and lavander (Lavandula stoechas L.). Food Chem 87: 393-400.

28. Jirovetz L, Buchbauer G, Stoilova I, Stoyanova A, Krastanov A, et al. (2006) Chemical composition and antioxidant properties of clove leaf essential oil. $J$ Agric Food Chem 54: 6303-6307.

29. Yanishlieva NV, Marinova EM, Gordon MH, Raneva VG (1999) Antioxidant activity and mechanism of action of thymol and carvacrol in two lipid systems. Food Chem 64: 59-66.

30. Chinou IB, Bougatsos C, Perdetzouglou D (2004) Chemical composition and antimicrobial activities of Helichrysum amorginum cultivated in Greece. Journal of Essential Oil Research 16: 243-245.

31. Burt S (2004) Essential oils: their antibacterial properties and potential applications in foods - A Review. Int J Food Microbiol 94: 223-253.

32. Rivas L, McDonnell MJM, Burgess CM, O'Brien M, Navarro-Villa A, et al. (2010) Inhibition of verocytotoxigenic Escherichia coli in model broth and rumen systems by carvacrol and thymol. Int J Food Microbiol 139: 70-78.

33. Raybaudi-Massilia RM, Mosqueda-Melgar J, Martín-Belloso O (2006) Antimicrobial activity of essential oils on Salmonella enteritidis, Escherichia col and Listeria innocua in fruit juices. J Food Prot 69: 1579-1586. 